Planning: Monday, July 12, 11:30 a.m.-12:30 p.m.

Renaissance Bibliography: Tuesday, July 13, 8:00-9:00 p.m.
Research and Publications: Sunday, July 11, 9:30-11:00 a.m.

Social Sciences Discussion Group: Sunday, July 11, 2:00-4:00 p.m.

\title{
ACRL's Committee on an Activity Model for 1990: The Final Report
}

\section{FOREWORD}

The Association of College and Research Libraries is the fifth largest library association in the world, comprising more than 9,400 members. It is also the third oldest library association in the world, dating its origin from 1890 . In December 1980 David Weber, then vice-president of ACRL, appointed an ad hoc committee to review the Association's activity structure and propose such changes as appeared needed to bring it into accord with the likely demands of its second century of service to begin in 1990 .

Vice-president Weber's charge to this new "Committee on an Activity Model for 1990" was to conceptualize an

activity program to help shape the directions of Association efforts in the years immediately ahead; to raise thereby the sights of ACRL members, sections, and officers for ACRL achievement; and to stimulate membership interest and involvement in the advancement of the Association.

Persons appointed to the Committee were Olive James, David Kaser, Carla Stoffle, William Studer, and Julie Virgo.

The Committee's first concern was to determine what purpose or ends its "Activity Model" should be designed to attain. Finding no recent statement of Association goals and objectives that it could utilize, the Committee set about to develop one through the use of a planning pyramid of objectives, shown here as Figure 2.

In accord with this dialectic for planning, the Committee began by reviewing both "environmental considerations" and "internal characteristics" (as shown at the top of the pyramid) which could be expected to affect Association fortunes during the coming decade. They are given as Sections II and III of this Report. Taking those factors into account, the Committee then drafted a statement of "Mission" and "Goals" which it proposed to the membership in the May 1981 issue of $C \triangleleft R L$ News. After appropriate revision of the statement, the Committee fashioned a set of "Objectives" to fit the Goals, and it now commends all three parts (e.g., Section III of this Report) to the Board of Directors for possible adoption.
The Committee then set to work on its main charge to develop an Activity Model for meeting these purposes. It reviewed all past and present activities of ACRL, as well as a wide range of additional possibilities for action, and it concluded that the best model possible would be a modification of ACRL's present program. In its judgment, the Association would be able to meet these goals successfully and carry a strong program into its second century if, in addition to such present activities as are not affected by this Report, ACRL were also to address the new activities enumerated in Section IV. Although that list also suggests possible appropriate action for each item therein, the Committee recommends that the Board refer the entire list to the Planning Committee for item-by-item review and recommendation. Resources may need to be considered, and priorities may have to be assigned, before it can be adopted, either in whole or in part.

In conclusion, the Committee recommends that the Association adopt an identifying slogan or logo for this program. It presents Figure 1 for possible consideration.

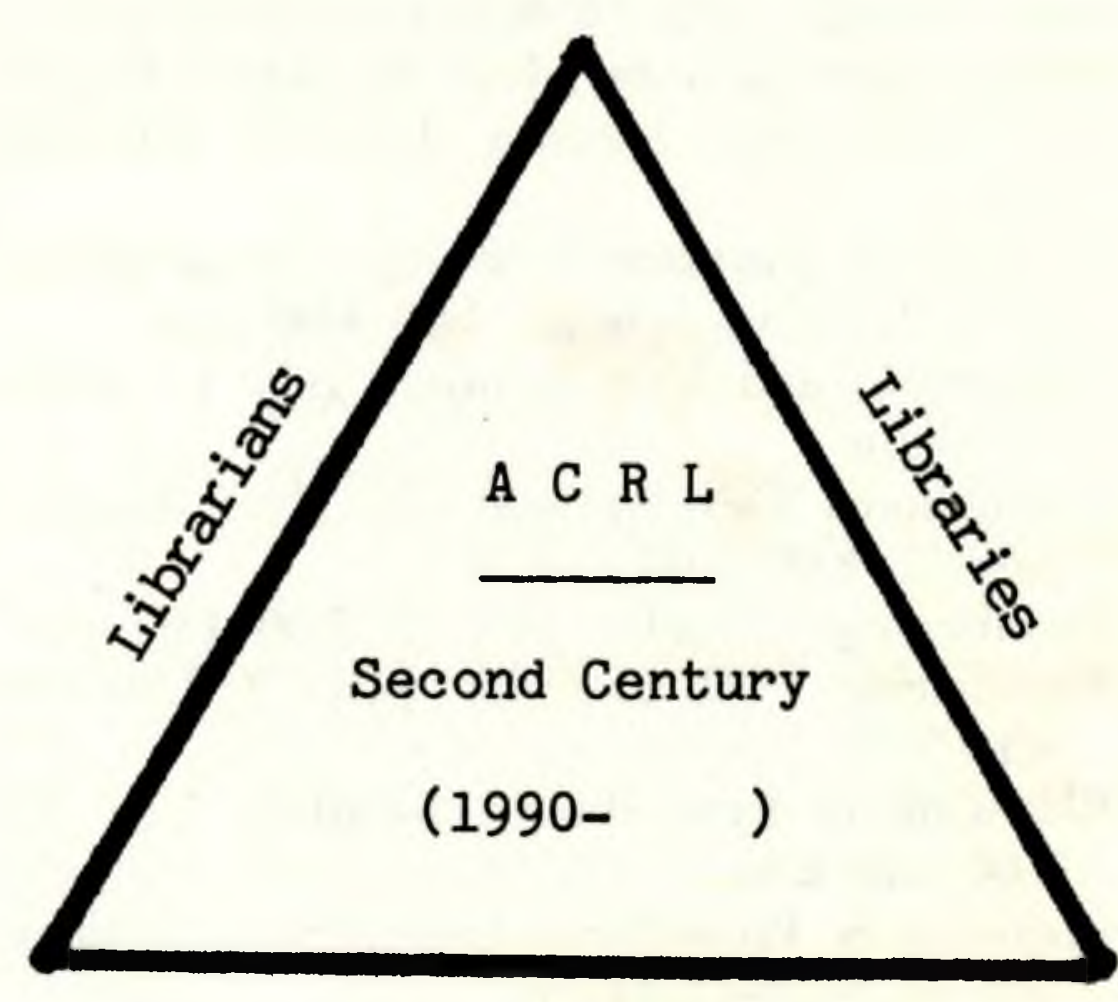

Librarianship

Fig. 1. Possible Logo 


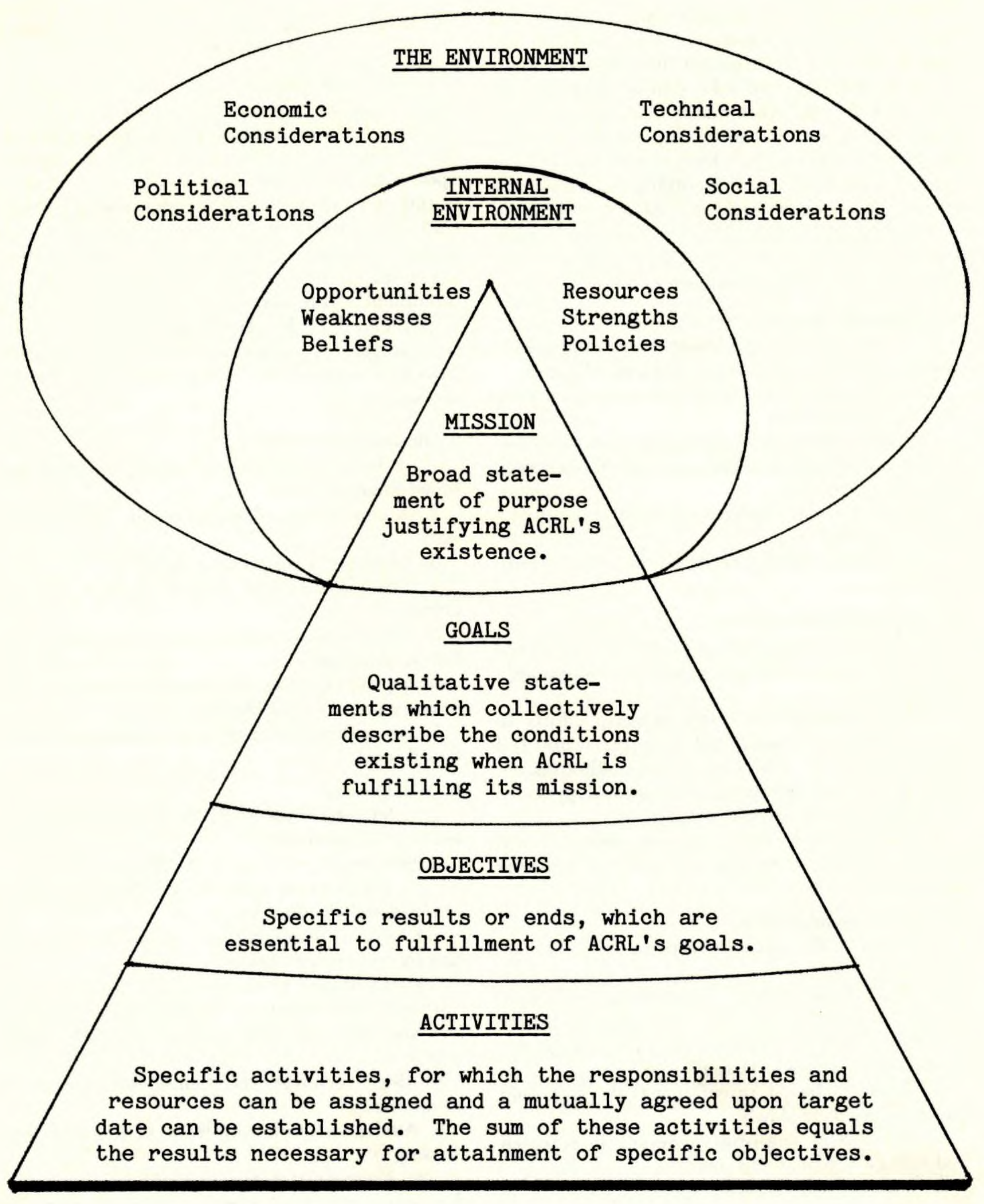

Fig. 2. Planning Model. 


\section{EnVironmental Considerations Likely to AFFECT ACRL ACTIVITIES IN 1990}

No reasonable set of goals and objectives can be conceived in a vacuum. To be realistic, the aspirations of an organization, like the aspirations of an individual, must take into account any environmental constraints that will impair or retard progress and are beyond the organization's ability to alter or remove. For purposes of the present exercise, the Committee identified four categories of such intransigent realities that it felt it would be prudent to respect; they are economic, political, social, and technical. The principal items among these considerations are as follows:

\section{A. Economic Considerations}

1. Steady-state or declining purchasing power will be available to academic/research libraries.

2. Costs of word processing/communication services will decline.

3. Profit-sector information services will become increasingly available to higher education/ research personnel.

4. Inflation will continue at least through the next five years.

5. Libraries will be expected to increase productivity.

\section{B. Political Considerations}

1. Federal government attitude toward academic/research libraries will be increasingly laissez-faire.

2. State governments will increase efforts to centralize authority/control over tax-supported higher education, including academic libraries.

3 . There will be rising international pressure for bibliographical standardization.

4. The political impact of local consortia will decline, as that of regional and national consortia increases.

\section{Social Considerations}

1. Society will continue to press for dollar accountability.

2. Traditional college enrollments will hold steady or decline, but the demographic profile and educational needs/expectations of college students will continue to change.

3. Academy-based research activity will hold steady or advance slowly.

4. The use of non-print materials in research and college teaching will increase.

5. Society will demand speedier delivery of information/documents from library repositories.

\section{Technical Considerations}

1. Word processing/communication/computer technology will improve.

2. Publishing will continue to move to singlecopy on-demand delivery.

3. Labor intensity in the library/information field will decline.

4. Paper in existing library book stocks will continue to disintegrate.
5. Personal ownership of word processing/ computing hardware will increase rapidly.

\section{Internal Characteristics Likely to AfFect ACRL's FUTURE}

In the same manner, attainable goals and objectives can be built only upon a frank assessment of characteristics internal to the group that are likely either to support or to impede the agreedupon activities of the organization. The purpose of this assessment is to determine and set in motion appropriate strategies for enhancing the former and diminishing the latter, while fashioning a set of organizational intentions capable of fulfillment. Here the Committee reviewed what it perceived to be ACRL strengths/resources, weaknesses, opportunities, and beliefs/policies. Principal among these characteristics are the following:

\section{A. Resources/Strengths}

1. A large membership $(9,400)$, providing a broad financial base.

2. A committed, although small, headquarters staff.

3. Adequate headquarters facilities.

4. Good flow of cost data on services and programs.

5. An effective, regular, and diversified publishing program.

6. A program of services aimed at individual librarians as well as at libraries.

7. An appropriate governance structure at the Board level.

\section{B. Weaknesses}

1. Ineffective methods of identifying membership wishes/needs.

2. Structural problems in ACRL governance:

a. Poor communication/coordination among committees, sections, chapters;

b. Terms of office too brief for optimum action by committee chairs;

c. Reluctance to abort inactive units.

3. Inequities between ACRL subsidies to chapters and some chapter services to ACRL members.

4. High turnover and inadequate growth in membership.

5. Aberrations resulting from ACRL-ALA relationship:

a. Absence of autonomous bursary prevents development of fund reserves, accrual of interest on balances, etc.;

b. Interlocking dues structure impairs ACRL ability to give a full measure of service for dues paid;

c. ALA support services, salary schedules, operating policies, etc., are often inadequate to ACRL needs;

d. ACRL has difficulty gaining adequate visibility or speaking out on critical national library issues except by ALA sufferance; 
e. ACRL national conference needs, revenues, scheduling, etc., are frequently at variance with ALA's.

\section{Opportunities}

1. The times may be right to effect some changes:

a. Recent successful conferences and services have created climate for change; change;

b. Members and officers are pressing for

c. ALA administration appears willing to hear proposals for change.

2. Current state of academic/research library community requires stronger ACRL voice.

3. Methods and technologies are becoming available for enhancing ACRL service capabilities.

4. Growth in membership seems possible, as result of:

a. Greater sense of professional community being stressed in library schools;

b. Increasing network/cooperative programs demonstrate need for "extra-library" professional involvement;

c. Better-attuned member services raise value of belonging.

5. Recognition of academic/research library significance is increasing among non-library organizations.

\section{Beliefs/Policies}

No current ACRL beliefs or policies are viewed as being impervious to change where the need for such change can be demonstrated.

\section{ACRL Mission, GoAls, And Objectives}

An appropriate Mission statement for an organization, or "broad statement of purpose justifying” its existence (see Figure 2), will represent a high degree of match between its ability on the one hand and the social need for it on the other. Thus the Committee proposes the ACRL state as its mission: to foster the profession of academic and research librarianship. It further recognizes four Goals, or "qualitative statements which collectively describe the conditions existing when ACRL is fulfilling its Mission." These goals express the Association's functions regarding librarians, libraries, and librarianship, as well as research on these matters. For each Goal, the Committee then suggests herein a number of Objectives, or "specific results or ends which are essential to fulfillment of ACRL's Goals."

It is the Committee's hope that the Association will adopt the following statement of Mission, Goals, and Objectives as ACRL policy and use it on a continuing basis, with periodic review and revision, to appraise the legitimacy of existing or proposed organizational activities.

MISSION: To foster the profession of academic and research librarianship.

GOAL NO. 1. To contribute to the total pro- fessional development of academic and research librarians.

\section{OBJECTIVES:}

A. To sponsor and encourage opportunities for academic and research librarians to update existing competencies, learn requisite new skills, and gain awareness of the state of the art.

B. To publish reports that will advance the professional knowledge and understanding of academic and research librarians.

C. To inform academic and research librarians of developments in the profession and in higher education.

D. To provide structured opportunity for academic and research librarians to participate in determining the future of the profession.

E. To afford a sense of professional identity and peer reinforcement to academic and research librarians.

F. To provide career counseling and placement information regarding academic and research librarianship.

GOAL NO. 2. To improve service capabilities of academic and research libraries.

\section{OBJECTIVES:}

A. To provide appropriate standards and guidelines (e.g. personnel, collections, facilities, references, instruction, etc.).

B. To provide advisory services to libraries and to academic institutions.

C. To encourage innovation in academic and research library services.

D. To encourage fiscal and political support for academic and research libraries, including support of appropriate legislation at all levels.

GOAL NO. 3. To promote and speak for the interests of academic and research librarianship.

\section{OBJECTIVES}

A. To further recognition of librarians as full partners in the academic enterprise.

B. To enhance awareness of the role of academic and research libraries among such groups as accrediting bodies, government agencies, higher education associations, scholarly and professional organizations, other segments of the library profession, and the general public.

C. To support and participate in the recruitment of promising persons to the field.

D. To monitor and help shape library education programs in accord with the needs of academic and research librarianship.

E. To effect alliances with other professional and scholarly organizations and agencies that share interests with academic and research libraries.

F. To monitor and speak out upon government activities of potential impact upon academic and research librarianship. 
G. To represent academic and research library concerns within other professional bodies.

GOAL NO. 4. To promote study and research relevant to academic and research librarianship.

\section{OBJECTIVES:}

A. To sponsor a strong publishing program.

B. To encourage and sponsor forums for the discussion and dissemination of research results.

C. To promote awareness of the need for research and encourage improvement in research skills.

D. To identify and publicize issues and topics requiring study and research.

E. To seek funding for, and to commission, appropriate research projects.

F. To encourage research leaves for academic and research librarians.

G. To encourage, endorse, participate in, and disseminate the results of relevant research undertaken outside the library profession.

H. To inform members as needed of relevant research in progress.

\section{Additional ACRL ACtivities Needed}

If this were a complete strategic and tactical planning exercise, the Committee would have proceeded, as is shown in the bottom step of the illustration in Figure 2, to enumerate an entire range of appropriate activities, the sum of which would "equal the results necessary for attainment" of the Goals and Objectives laid out in Section III above. That, however, was not its charge. The Committee was charged rather to propose an Activity Model for ACRL appropriate to the 1990 s.

It is the Committee's judgment that, given some modest enlargements, modifications, and curtailments, the existing ACRL structure will be able to continue to serve into its second century. It therefore identifies in this Section only such additional or changed activities as it feels will be needed for successful attainment of its Mission in the 1990s, when accomplished alongside of any existing activities not affected by this document.

As we indicated in the Foreword, the Committee also suggests what it perceives to be appropriate action for each Activity listed here. Its recommendation, however, is that the Board of Directors refer this Section of the Report to the Planning Committee for item-by-item review and recommendation.

\section{A. Membership Activities}

1. Conferences and Workshops.

a. Study alternate formats for national conferences (e.g., frequency, structure, length, location, etc.). Action: Refer to ad hoc committee.

b. Study alternate modes of conference and workshop delivery (e.g., decentralized, televised, video-taped, etc.). Action: Refer to ad hoc committee.

c. Encourage establishment of more discussion groups on wider range of topics (e.g., education for academic librarianship, recruitment, research, women's studies, etc.). Action: Refer to Planning Committee.

d. Institute market analyses of conference/ workshop needs. Action: Refer to ad hoc committee.

\section{Publications.}

a. Consider new formats for $C \triangleleft R L$ (e.g., more pages, increased frequency, monographic supplements, separate sections for discussion and research reports, section newsletters, etc.). Action: Refer to $C \mho R L$ Editorial Board.

b. Study alternate modes for supplementary publishing (e.g., microform, single copy/on demand, online, etc.). Action: Refer to Publications Committee.

c. Consider newsletter, or column in an existing journal, addressed to higher education community (e.g., colleges and universities, accrediting bodies, government agencies, etc.). Action: Refer to Publications Committee.

3. Continuing Education Offerings.

a. Develop and coordinate $\mathrm{CE}$ offerings into an integrated "curriculum" of presentations at progressive grade levels. Action: Refer to Continuing Education Committee.

b. Seek out and relate ACRL CE program to useful parallel offerings of other agencies. Action: Refer to Continuing Education Committee.

c. Develop CE packages for multiple modes of delivery (e.g., mail, televised, individual or group use, CAI, etc.). Action: Refer to Continuing Education Committee.

\section{Chapters.}

a. Encourage establishment of more chapters at local level. Action: Refer to Chapters Committee.

b. Renew efforts to rationalize ACRL/chapter relationships (e.g., review ACRL funding of chapters and allowing chapter membership to nonmembers of ACRL, etc.) Action: Refer to Planning or ad hoc Committee.

c. Deliver more services (programming, counseling, etc.). through chapters (in lieu of funding?). Action: Refer to Planning or Chapters Committee.

\section{Advisory Services.}

a. Enlarge career counseling and placement activities (e.g., develop online employment service, job exchange roster, internship directory, etc.). Action: Refer to Staff.

b. Broaden advisory/referral capability (develop skills directory, consulting roster, etc.). Action: Refer to Staff.

\section{B. Administrative Activities}

\section{Board of Directors.}

a. Assign a Board member to meet with and 
act as liaison, but not as advocate, for each committee. Action: Refer to Executive Committee.

b. Establish a Public Information Committee, comprising ACRL past president, councilor, and executive director, to coordinate the communication of Association views to the larger library community. Action: Refer to Executive Committee.

c. Make Planning Committee responsible for short-range planning and periodic review of long-range goals and objectives. Action: Refer to Planning Committee.

d. Encourage greater cost consciousness within the Board. Action: Refer to Board.

\section{Sections and Committees.}

a. Hold orientation sessions for all new committee appointees. Action: Refer to Staff.

b. Sponsor leadership/group dynamics workshops for new elected officers and committee chairs. Action: Refer to Staff.

c. Encourage prompt action by, and discharge of, ad hoc committees. Action: Refer to Board and Sections.

d. Encourage economy in committee operations (e.g., by relieving Staff of committee paperwork, etc.). Action: Refer to Board, Sections, Committees, Staff.

\section{Headquarters.}

a. Commission study of work load and flow in ACRL office. Action: Refer to Executive Committee.

b. Upgrade executive staff to equivalency with strong academic library directorate. Action: Refer to Executive Committee.

c. Enlarge and seek greater permanence in headquarters personnel in accord with these goals and objectives. Action: Refer to Executive Committee.

d. Commission design of improved Management Information System (MIS) program (re members, costs, revenues, etc.) to aid in decision making. Action: Refer to Budget and Finance Committee.

e. Become primary voice in support of these objectives in all forums (e.g., government agencies, professional circles, scholarly community, etc.). Action: Refer to Executive Director.

f. Develop capability to sample membership opinion reliably and quickly (e.g., for program evaluation, priority determination, etc.). Action: Refer to Staff.

g. Study comparative costs of in-house and contracted services (re MIS, conference planning, publishing, telecommunication, etc.). Action: Refer to Staff.

\section{Support Services.}

a. Commission cost analysis of electronic mail system between headquarters and members, libraries, committees, officers, etc. Action: Refer to Executive Committee.

b. Commission feasibility study of utilizing teleconferencing techniques to (1) extend pro- gram delivery capability to local, regional, and national audiences; and (2) facilitate conduct of Board, section, and committee business. Action: Refer to Executive Committee.

c. Study conversion of present ACRL data bases, and the development of future files, for online remote terminal access (e.g., committee rosters, research-in-progress files, skills directories, placement listings, committee histories, etc.). Action: Refer to Executive Committee.

d. Seek funding for program of incentive awards (e.g., for best research, most innovative idea, most active chapter, etc.). Action: Refer to Planning Committee.

Editor's Note: The Activity Model Committee consists of David Kaser (chair), Indiana University; Olive C. James, Library of Congress; William J. Studer, Ohio State University; Carla J. Stoffle, University of Wisconsin-Parkside; and Julie Carroll Virgo, ACRL executive director.

\section{NEH Programs}

\section{in the Humanities}

Hidden among the redwoods and Douglas fir in the coastal hills near Los Gatos, California, the Presentation Center run by the Sisters of the Presentation of the Child was the scene of the second NEH/ACRL workshop on humanities programming, February 23-25. With clear weather, the temperature a balmy $60^{\circ}$, birds chirping, flowers blooming, and the lazy atmosphere of a placid hacienda, the center provided an ideal retreat for librarians and humanists to meet, compare notes, and learn the fundamentals of writing grant proposals for programs to bring library materials in the humanities to people in their community.

A National Endowment for the Humanities grant of $\$ 64,549$ allowed for the two workshops, the first of which was held in Shrewsbury, Massachusetts, on November 30-December 2, 1981. Twenty-six teams of one librarian and one faculty humanist from each institution attended the Los Gatos workshop, and twenty-five teams met in Shrewsbury. Because of the limits on attendance, this represented only about $45 \%$ of all those who applied.

Many in the group that attended the California workshop had already begun to plan humanities programs. Sonoma State University was considering a program targeted for the Indochinese population in their area. Georgia Southern College had been studying a program on noted Georgians. Other institutions were focusing on senior citizens, Native Americans, local artists and authors, and other special interest groups or re- 